\title{
Investigating Organizational Alienation Behavior in Terms of Some Variables
}

\author{
Abidin Dağli ${ }^{1, *}$, Emel Averbek $^{2}$ \\ ${ }^{1}$ Ziya Gokalp Education Faculty, Department of Educational Administration, Dicle University, Turkey \\ ${ }^{2}$ Mehmet Akif Nuhoglu Vocational and Technical Anatolian High School, Turkey
}

Copyright $\bigcirc 2017$ by authors, all rights reserved. Authors agree that this article remains permanently open access under the terms of the Creative Commons Attribution License 4.0 International License

\begin{abstract}
The aim of this study is to detect the perceptions of public primary school teachers regarding organizational alienation behaviors in terms of some variables (gender, marital status and seniority). Survey model was used in this study. The research sample consists of randomly selected 346 teachers from 40 schools in the central district of Mardin, Turkey in 2015-2016 academic year. "Organizational Alienation Scale" developed by Eryılmaz (2010) was applied to the teachers. The level of significance was 0.05 . Some of the important findings were listed respectively; (I) the three items with the highest levels related to the perceptions of public primary school teachers about organizational alienation behaviors: (1) I feel burnout and worn at work ( $\mathrm{M}=2.53$, Rarely), 2) I think bureaucratic process at school impels me to obey unconditionally ( $M=2,51$; Rarely), (3) As soon as I finish my lessons, I want to leave the school $(M=2,45$; Rarely). The three items with the lowest levels (1) I think teaching is a useless activity $(\mathrm{M}=1.27$, Never), (2) I feel excluded at school $(\mathrm{M}=1,30$; Never) and (3) I evaluate myself as an individual without a contribution to the society ( $\mathrm{M}=1,31$; Never). II). Significant difference was detected in all dimensions except in self-alienation with respect to the teachers' gender. No significant difference was detected in the dimensions of organizational alienation behaviors regarding teachers' marital status. Finally, significant difference was detected in the dimension of powerlessness and meaninglessness regarding professional seniority.
\end{abstract}

Keywords Alienation, Organizational Alienation, Primary School

\section{Introduction}

The root of the notion of alienation is based on "aliéné" in French, "alienado" in Spanish and "alienation" in English [1]. Feuerlicht (1978) has pointed out to the fact that alienation with Latin origin has a long history and it was seen in works by first theologians such as Calvin and Luther. Furthermore, in theological sense, alienation means people's being alienated from God after Adam and Eve's expulsion from Paradise [2].

Generally, the concept of alienation can be defined as a decline in an individual's harmony with social, cultural and natural surrounding and a decrease especially in the control over his/her close surrounding, which causes loneliness and despair [3]. Literally, alienation denotes individuals' estrangement from themselves and certain milieu or a process [4].According to Allan (2012), it also pertains to feelings of despair, anomie, isolation, anxiety, dissociation, loss of identity and a mind numbing experience. Furthermore, this phenomenon is popularly seen as a key influence over work performance, intention to quit, job commitment, burn-out and loyalty to the organization [5]. Work alienation is a state of psychological disengagement that generalizes across one's self-image and social relationships both inside and outside of the work [6]. Since the most basic understanding of alienation involves a separation or estrangement and given the varying targets of this separation, work alienation is defined as estrangement or disconnect from work, the context or the self [7].The symptoms of alienation are estrangement, apathy, inability to be deeply committed to anything, lack of work engagement, retreating, disconnection in relationships and isolation [8]. Alienation can be described as a sense of estrangement from other human beings, from society and its values, and from the self, particularly from those parts of the self that link it to others, and to society at large [9]. According to Fromm, alienation is the most serious problems of modern times [10]. An alienated person is unhappy and that person tries to save time; however, s/he also has a craving for killing the time that $\mathrm{s} / \mathrm{he}$ endeavours to save [11]. Although alienation results from social factors, it occurs within a person. The groups thinking that they are alienated from the society or being thought as alienated suffer from the fact that they either cannot perform their individual qualities or they are not allowed to perform these qualities although they are compatible with the system of social values. Both cases that give rise to alienation from 
society are called self-alienation [12].

The concept of organizational alienation refers to an attitude or a condition in which an employee cares little about work, approaches work with little energy and works primarily for extrinsic rewards [13] or it refers to the impossibility of meeting employees' social requirements [14]. Organizational alienation is described as the reflection of an individual's feelings caused by the disappointment about a person's employment situation [15].

Seeman (1959) evaluated alienation in terms of socio-psychological view and postulated five dimensions -powerlessness, meaninglessness, normlessness, isolation, and self-estrangement. These dimensions are described briefly below [16].

1. Powerlessness: According to Blauner (1964) and West (1998), alienation in the form of powerlessness results from an individual's separating from the product that $\mathrm{s} / \mathrm{he}$ has produced on her/his own, a feeling of inadequacy due to being ineffective over administrative/organizational policies and lack of control over working conditions. Powerlessness is a situation created by a bad mood in which individuals are unable to conduct the organizational activities or decide on their own [17].

2. Meaninglessness: In organizational term, Shepherd (1972) suggests that meaninglessness occurs when there is a conflict between organizational aims and personal roles. Employees just know their work and have no idea about colleagues' work and other departments' duties; hence employees are not aware of their contribution to their organizations [17].

3. Normlessness (Anomie): It can be defined as an imbalance which occurs as a result of the lack of aims or the collapse of values and dimensions within the individuals or in the society [18].

4. Isolation: It is the result of the fact that members of organizations retreat themselves from their surroundings and have the feelings of the inability to belong to any group or community, which shows itself in two ways. Firstly, an individual thinks that $\mathrm{s} / \mathrm{he}$ is refused or not wanted by a group. Secondly, an individual refuses or does not want a group or the community which s/he belongs to [17]. Employees cannot make friends and they have difficulties in communicating with people and they separate from their social circles [19].

5. Self- estrangement: Mottaz (1981) points out the fact that employees don't perform their job fondly and they don't find their jobs interesting. They cannot make any connection between the things that they want to do and the job that they perform. Thus, they cannot experience the feeling of happiness resulting from success [17]. Self-estrangement occurs when an employee does not find their job satisfactory [20].

Alienation has been identified with a number of problems and negative consequences. These problems were found within the work organisation; however, it has wider social and psychological consequences. The unconstructive consequences of alienation identified within the workplace were; employee turnover, employee dissatisfaction, lower worker commitment, absenteeism, employee sabotage (Hodson and Sullivan, 2011), lower productivity (Abraham, 2000), and aggression amongst individuals, and groups (Freudenberger, 1980), and (Abraham, 2000) employee burnout, which further decreased workers' productivity [5]. Diener (1984) pointed out the fact that the self-esteem of alienated workers is likely to be low. Korman (1966) and Sirgy (1986) suggest that workers with low self-esteem tend to have lower levels of performance and alienated workers feel incompetent, which leads to dissatisfaction with the job and an escape from work [21]. The consequences of feeling apart from one's society are little known. Several possibilities have been suggested: (1) That alienation is related to creativity, (2) That alienation is related to mentalemotional disorder, (3) That alienation is related to altruism, (4) That the alienated suffer a proclivity to suicide, (5) That they are prone to the chemical addictions, (6) That they are poor marriage risks, (7) That their estrangement leads to criminal behavior [22].

Shepard (1973) defined alienation as an awareness of a discrepancy between one's own inclinations and the demands of reality. When what we want, believe in, and intend is at odds with what reality affords, then we tend to become alienated. We disassociate ourselves from the context or situation. Teachers also become alienated when there is a discrepancy between their demands and expectations [23].

The phenomenon of alienation in education appears to be a problem that influences teachers directly. The estrangement of people in educational organizations from processes related to learning, teaching and those processes becoming meaningless for individuals and a lack of interest in education result in the fact that education turns out to be boring and unpleasant. Moreover, alienation in education can also be explained in a way that individuals working within organizations feel excluded at school, they think they are discriminated and they feel estranged firstly from their collgues and then from themselves. Alienation is observed to have considerable effects especially on schools. Teachers are affected by social, psychological, financial and organizational factors during their work life. The characteristics and types of organizations in which teachers work, the reasons for choosing the job, the importance they give to their work, family life-styles are the determinants that influence teachers' alienation from their organizations. Since the phenomeonon of alienation perceived by teachers affects their psychological situation, their perspective on life and their performances within the organizations, it is crucial to determine the level of their alienation in order to improve the quality of organizational life [17]. Alienation prevents teachers' creativity, their becoming a model for their students and the society and improving themselves professionally. Furthermore, it is an obstacle to their contribution to social development, to their influence on the 
process of learning and teaching, to their productivity in teaching and to their collaborating with school administration and colleagues [24]. All forms of teacher dissatisfaction engender feelings of alienation and that the oppressive nature of alienation is the root cause of all the negative consequences associated with teacher dissatisfaction [25]. It is not possible for teachers experiencing work alienation to help the students in critical periods in respect to learning and pesonality development. Furthermore, they avoid taking responsibilties because they think they will be unsuccessful [26].

As alienation is thought to be one of the factors that decrease the productivity, it is significant to determine in which dimensions the primary school teachers' level of alienation is more and how to do away them. This study is hoped to shed light on this suject for administrators, teachers and researchers who will study on alienation.

\subsection{The Aim of the Study}

The aim of this study is to detect the perceptions of public primary school teachers regarding organizational alienational behaviors in terms of some variables (gender, marital status and seniority). It was tried to answer the questions below;

1.1.1. What is the range of the perceptions of primary school teachers regarding organizational alienation behaviors?

1.1.2. Is there a significant difference regarding the perceptions of the primary school teachers about organizational alienation behavior according to;

\subsubsection{Gender}

1.1.2.2. Marital status

\subsubsection{Seniority}

\section{Materials and Methods}

\subsection{The Model of the Study}

This study is in survey model. In survey model the person or the object of the study is tried to be determined in its own conditions as it is [27].

\subsection{Population and Sample}

The population of the study consisted of primary school teachers in the central district of Mardin in 2015-2016 academic year. There are 90 primary schools in the central district of Mardin in Turkey and 700 primary school teachers. The sample was made up of 346 teachers in 45 primary schools.

\subsection{Data Collection Tool}

Organizational Alienation Scale was used in this study. The information related to data collecting is described below:

Organizational Alienation Scale: Organizational Alienation Scale was both developed and validity and reliability were carried out by Eryılmaz (2010)[28]. There are four items for personal information in the scale and 38 items for organizational alienation level. The dimensions in the scale and items can be described as; 15 items for powerlessness $(1,2,3,4,5,6,7,8,9,10,11,12,13,14,15)$, 10 items for meaninglessness $(16,17,18,19,20,21,22,23$, 24, 24), 4 items for normlessness $(26,27,28,29), 6$ items for isolation $(30,31,32,33,34,35)$ and 3 items for self estrangement $(36,37,38)$. Cronbach alpha coefficient of the dimensions was re-evaluated and detected as ; 0,$94 ; 0,89$; 0,$64 ; 0,80 ; 0,64$. It is 0,94 for the whole scale. It is accepted that reliability co-efficient with 0.70 and over is regarded as reliable [29]. When there are not many items in the scale, reliability co-efficient with 0.60 and over is also regarded reliable enough [30]. Özdamar (1999) pointed out that evaluations are highly reliable when alpha reliability coefficient is between 0.60 and 0.90 [31]. Thus, Cronbach Alpha reliability coefficient acquired through the evaluations is within the acceptable limits. The answers in the scale; always (5), Usually (4), Sometimes (3), Rarely (2) and Never (1).

SPSS 20.0 packet programme was used for the analysis of the data. Frequencies were calculated according to some qualities of the working group. Mean scores and standard deviations of the items, the dimensions and the points of the whole scale were calculated in order to evaluate the data obtained through this study. Furthermore, since the points did not belong to any particular distribution, nonparametric tests were used. Thus, nonparametric tests such as Mann-Whitney $U$ test and the Kruskal-Wallis test were used. When there was a significance difference, Kruskal Wallis Test was used. Mann Whitney U-Test was used to find out the reason for the difference. When evaluating items in organizational alienation, the values between 1,00 and 1,80 were accepted as "Never"; the values between 1,81 and 2,60 as "Rarely"; the values between 2,61 and 3,40 as "Sometimes"; the values between 3,41 and 4,20 as "Usually"; the values between 4,21 and 5,00 as "Always".

\section{Findings}

This part includes the findings related to; (1) What is the range of the perceptions of primary school teachers regarding organizational alienation behaviors? and (2) Is there a significant difference regarding the perceptions of the primary school teachers about organizational alienation behavior according to; gender, marital status, seniority

\subsection{The Teachers' Perceptions Regarding Organizational Alienation}

Mean rank of the perceptions of primary school teachers regarding organizational alienation behaviors was shown in Table 1 below. 
Table 1. The Mean rank and standard deviations of the perceptions of teachers regarding organizational alienation behavior

\begin{tabular}{|c|c|c|c|c|}
\hline & & M & SD & LEVEL \\
\hline 1 & I think the contribution that I make for my students is not enough & 2.12 & 1.85 & Rarely \\
\hline 2 & I have difficulty communicating with my students & 1.74 & .82 & Never \\
\hline 3 & I feel burnout and worn at work & 2.53 & 1.19 & Rarely \\
\hline 4 & I think the contribution that I make for school administrative activities is not enough & 2.13 & 1.03 & Rarely \\
\hline 5 & I feel I am losing the will and excitement for work & 2.04 & 1.05 & Rarely \\
\hline 6 & I think I cannot have the friend support that I need at school & 1.89 & 1.04 & Rarely \\
\hline 7 & I feel I am being exploited related to work issues by my colleagues & 1.41 & .86 & Never \\
\hline 8 & I feel there is nothing that will change no matter how I work & 1.99 & 1.08 & Rarely \\
\hline 9 & I think my thoughts are not given importance & 1.76 & 1.04 & Never \\
\hline 10 & I think I don't have the control over classroom management & 1.50 & .86 & Never \\
\hline 11 & I feel I am losing the stregth of he struggle to deal with school problems & 1.80 & .92 & Never \\
\hline 12 & I prefer remaining unresponsive about the injustices that do not concern me & 1.90 & .99 & Rarely \\
\hline 13 & I think that my views are not asked about decisions related to my work & 1.90 & 1.05 & Rarely \\
\hline 14 & I feel I cannot do anything to overcome conflicts at school. & 1.94 & 1.03 & Rarely \\
\hline 15 & I think bureaucratic process at school impels me to obey unconditionally & 2.51 & 1.25 & Rarely \\
\hline 16 & I think the subjects taught at shool are not useful for real life & 2.08 & 1.11 & Rarely \\
\hline 17 & I feel fed up with teaching the same things at school & 1.97 & 1.05 & Rarely \\
\hline 18 & I feel as if I am doing a meaningless job at school. & 1.52 & .92 & Never \\
\hline 19 & As a teacher, I feel myself as useless and unimportant. & 1.42 & .86 & Never \\
\hline 20 & I regard the efforts of my colleagues who perform teaching idealistically as unnecessary & 1.39 & .79 & Never \\
\hline 21 & I think teaching is a useless activity & 1.27 & .68 & Never \\
\hline 22 & I think teaching is boring. & 1.77 & .95 & Never \\
\hline 23 & I regard teaching just as a source of income & 1.50 & .91 & Never \\
\hline 24 & I feel I am a programmed robot for taking a class. & 1.85 & 1.06 & Rarely \\
\hline 25 & I think attending the meetings related to my work is meaningless. & 1.88 & 1.11 & Rarely \\
\hline 26 & I think school rules are not applied equally for all teachers. & 2.32 & 1.31 & Rarely \\
\hline 27 & I do not care if my behaviors are appropriate for legislations and rules. & 1.64 & .98 & Never \\
\hline 28 & I apply the rules that I make at school & 2.22 & 1.26 & Rarely \\
\hline 29 & I think rules at school prevent my creativity. & 2.44 & 1.17 & Rarely \\
\hline 30 & I try not to meet other teachers and administrators if it is not obligatory & 1.66 & 1.02 & Never \\
\hline 31 & I feel excluded at school. & 1.30 & .79 & Never \\
\hline 32 & I think relationships at school are not sincere. & 2.20 & 1.21 & Rarely \\
\hline 33 & I do not like having the responsibility related to activities outside classroom. & 2.28 & 1.20 & Rarely \\
\hline 34 & I do not want to do any activities with other teachers outside school & 2.02 & 1.18 & Rarely \\
\hline 35 & I think my circle of friends are boring. & 1.73 & .97 & Never \\
\hline 36 & I experience emotional emptiness in my life & 1.82 & 1.00 & Rarely \\
\hline 37 & As soon as I finish my lessons, I want to leave the school & 2.45 & 1.22 & Rarely \\
\hline 38 & I evaluate myself as an individual without a contribution to the society & 1.31 & .76 & Never \\
\hline
\end{tabular}


Table 2. The results of Mann Whitney U Test about the teachers' perceptions regarding gender

\begin{tabular}{|c|c|c|c|c|c|c|c|}
\hline Dimension & Gender & $\mathrm{n}$ & Mean Rank & $\begin{array}{l}\text { Sum of } \\
\text { Ranks }\end{array}$ & $\mathrm{U}$ & Z & $\mathrm{P}$ \\
\hline \multirow{2}{*}{ Powerlessness } & Female & 190 & 163.66 & 31096.00 & \multirow{2}{*}{12951.00} & \multirow{2}{*}{2.021} & \multirow{2}{*}{$.043 *$} \\
\hline & Male & 156 & 185.48 & 28935.00 & & & \\
\hline \multirow{2}{*}{ Meaninglessness } & Female & 190 & 153.60 & 29184.50 & \multirow{2}{*}{11039} & \multirow{2}{*}{4.098} & \multirow{2}{*}{$.000^{*}$} \\
\hline & Male & 156 & 197.73 & 30846.50 & & & \\
\hline \multirow{2}{*}{ Normlessness } & Female & 190 & 155.76 & 29593.50 & \multirow{2}{*}{11448.50} & \multirow{2}{*}{3.659} & \multirow{2}{*}{$.000^{*}$} \\
\hline & Male & 156 & 195.11 & 30437.50 & & & \\
\hline \multirow{2}{*}{ Isolation } & Female & 190 & 158.58 & 30130.00 & \multirow{2}{*}{11985.00} & \multirow{2}{*}{3.075} & \multirow{2}{*}{$.002 *$} \\
\hline & Male & 156 & 191.67 & 29901.00 & & & \\
\hline \multirow{2}{*}{ Self Alienation } & Female & 190 & 165.56 & 31456.50 & \multirow{2}{*}{13311.50} & \multirow{2}{*}{1.651} & \multirow{2}{*}{.099} \\
\hline & Male & 156 & 183.17 & 28574.50 & & & \\
\hline \multirow{2}{*}{ The whole scale } & Female & 190 & 156.16 & 29669.50 & \multirow{2}{*}{11524.50} & \multirow{2}{*}{3.560} & \multirow{2}{*}{$.000^{*}$} \\
\hline & Male & 156 & 194.63 & 30361.50 & & & \\
\hline
\end{tabular}

$(* \mathrm{p}<.05)$

Table 3. The results of Mann Whitney U Test about the teachers' perceptions regarding marital status

\begin{tabular}{|c|c|c|c|c|c|c|c|}
\hline Dimension & $\begin{array}{l}\text { Marital } \\
\text { Status } \\
\end{array}$ & $\mathrm{n}$ & Mean Rank & $\begin{array}{l}\text { Sum of } \\
\text { Ranks }\end{array}$ & U & Z & $\mathrm{P}$ \\
\hline \multirow{2}{*}{ Powerlessness } & Married & 238 & 179.11 & 42628.50 & \multirow{2}{*}{11516.50} & \multirow{2}{*}{1.550} & \multirow{2}{*}{.121} \\
\hline & Single & 108 & 161.13 & 17402.50 & & & \\
\hline \multirow{2}{*}{ Meaninglessness } & Married & 238 & 176.67 & 42047.50 & \multirow{2}{*}{12097.50} & \multirow{2}{*}{.878} & \multirow{2}{*}{.380} \\
\hline & Single & 108 & 166.51 & 17983.50 & & & \\
\hline \multirow{2}{*}{ Normlessness } & Married & 238 & 176.46 & 41998.50 & \multirow{2}{*}{12146.50} & \multirow{2}{*}{.822} & \multirow{2}{*}{.411} \\
\hline & Single & 108 & 166.97 & 18032.50 & & & \\
\hline \multirow{2}{*}{ Isolation } & Married & 238 & 179.67 & 42762.50 & \multirow{2}{*}{11382.50} & \multirow{2}{*}{1.711} & \multirow{2}{*}{.087} \\
\hline & Single & 108 & 159.89 & 17268.50 & & & \\
\hline \multirow{2}{*}{ Self Alienation } & Married & 238 & 173.21 & 41223.00 & \multirow{2}{*}{12782.00} & \multirow{2}{*}{.082} & \multirow{2}{*}{.934} \\
\hline & Single & 108 & 174.15 & 188.08 .00 & & & \\
\hline \multirow{2}{*}{ The whole scale } & Married & 238 & 177.97 & 42358.00 & \multirow{2}{*}{11787.00} & \multirow{2}{*}{1.236} & \multirow{2}{*}{.217} \\
\hline & Single & 108 & 163.64 & 17673.00 & & & \\
\hline
\end{tabular}


Table 4. Kruskal-Wallis Test results about the teachers' perceptions of organizational alienation behavior regarding seniority

\begin{tabular}{|c|c|c|c|c|c|c|c|}
\hline Dimension & Seniority & $\mathrm{n}$ & Mean Rank & $\mathrm{sd}$ & $\chi^{2}$ & $\mathrm{p}$ & The reason for the difference \\
\hline \multirow{4}{*}{ Powerlessness } & $1-5$ years & 111 & 150.60 & \multirow{4}{*}{3} & \multirow{4}{*}{14.536} & \multirow{4}{*}{$.002 *$} & \multirow{4}{*}{$\begin{array}{l}1-5 \text { years and } 6-10 \text { years, } 1-5 \text { years } \\
\text { and } 11-15 \text { years, } 6-10 \text { years and } 16 \\
\text { +years, } 11-15 \text { years and } 16 \text { years } \\
\text { and over }\end{array}$} \\
\hline & $6-10$ years & 111 & 191.55 & & & & \\
\hline & $11-15$ years & 52 & 201.11 & & & & \\
\hline & 16 years and over & 72 & 161.04 & & & & \\
\hline \multirow{4}{*}{ Meaninglessness } & $1-5$ years & 111 & 154.72 & \multirow{4}{*}{3} & \multirow{4}{*}{10.606} & \multirow{4}{*}{$.014^{*}$} & \multirow{4}{*}{$\begin{array}{c}1-5 \text { years and } 6-10 \text { years, } 1-5 \text { years } \\
\text { and } 11-15 \text { years, } 11-15 \text { years and } \\
16 \text { years and over }\end{array}$} \\
\hline & $6-10$ years & 111 & 188.32 & & & & \\
\hline & $11-15$ years & 52 & 198.26 & & & & \\
\hline & 16 years and over & 72 & 161.73 & & & & \\
\hline \multirow{4}{*}{ Normlessness } & $1-5$ years & 111 & 169.95 & \multirow{4}{*}{3} & \multirow{4}{*}{.308} & \multirow{4}{*}{.959} & \\
\hline & $6-10$ years & 111 & 177.18 & & & & \\
\hline & $11-15$ years & 52 & 172.06 & & & & \\
\hline & 16 years and over & 72 & 174.34 & & & & \\
\hline \multirow{4}{*}{ Isolation } & $1-5$ years & 111 & 155.69 & \multirow{4}{*}{3} & \multirow{4}{*}{5.510} & \multirow{4}{*}{.138} & \\
\hline & $6-10$ years & 111 & 178.23 & & & & \\
\hline & $11-15$ years & 52 & 184.74 & & & & \\
\hline & 16 years and over & 72 & 185.54 & & & & \\
\hline \multirow{4}{*}{ Self- Alienation } & $1-5$ years & 111 & 168.99 & \multirow{4}{*}{3} & \multirow{4}{*}{6.562} & \multirow{4}{*}{.087} & \\
\hline & $6-10$ years & 111 & 179.23 & & & & \\
\hline & $11-15$ years & 52 & 197.85 & & & & \\
\hline & 16 years and over & 72 & 154.04 & & & & \\
\hline \multirow{4}{*}{ The whole scale } & $1-5$ years & 111 & 154.95 & \multirow{4}{*}{3} & \multirow{4}{*}{8.977} & \multirow{4}{*}{$.030^{*}$} & \multirow{4}{*}{$\begin{array}{c}1-5 \text { years and } 6-10 \text { years, } 1-5 \text { years } \\
\text { and } 11-15 \text { years. }\end{array}$} \\
\hline & $6-10$ years & 111 & 186.64 & & & & \\
\hline & $11-15$ years & 52 & 196.50 & & & & \\
\hline & 16 years and over & 72 & 165.22 & & & & \\
\hline
\end{tabular}

$(* \mathrm{p}<.05)$

As it is seen in Table 1, the first three items with the highest levels related to the perceptions of public primary school teachers about organizational alienation behaviors: (1) I feel burnout and worn at work ( $M=2.53$, Rarely), (2) I think bureaucraticprocess at school impels me to obey unconditionally ( $M=2,51$; Rarely), (3) As soon as I finish my lessons, I want to leave the school ( $\mathrm{M}=2,45$; Rarely).

The first three items with the lowest levels (1) I think teaching is a useless activity $(\mathrm{M}=1.27$, Never), (2) I feel excluded at school ( $\mathrm{M}=1,30$; Never) and (3) I evaluate myself as an individual without a contribution to the society $(\mathrm{M}=1,31$; Never $)$.

\subsection{The Evaluation of The Perceptions of The Teachers Regarding Organizational Alienation in Respect to Some Variables}

The findings about the significant difference in the perceptions of the primary school teachers about organizational alienation behavior according to (1) gender, (2) marital status and (3) seniority were shown below respectively.

\subsubsection{The teachers' Perceptions Regarding Gender}

Mann Whitney U Test was used to find out the significant difference about the teachers' perceptions regarding organizational alienation behavior in powerlessness, meaninglessness, normlessness, isolation and self- alienation in respect of gender. The findings were shown in Table 2.

As one can see in Table 2, there was a significant difference in all the dimensions except self alienation and in the whole scale regarding gender. Moreover, the level of organizational alienation of the male teachers was higher related to mean scores.

\subsubsection{The Perceptions Regarding Marital Status}

Mann Whitney U Test was used to find out the significant difference about the teachers' perceptions regarding organizational alienation behavior in powerlessness, meaninglessness, normlessness, isolation and self- alienation in respect to marital status. The findings were shown in Table 3.

In Table 3, there was no significant difference in all the dimensions and the whole scale regarding marital status. 


\subsubsection{The Perceptions Regarding Seniority}

Kruskal-Wallis Tests were used to find out the significant difference in the dimensions of powerlessness, meaninglessness, normlessness, isolation and self-realization regarding seniority and the findings were shown in Table 4.

As one can see in Table 4, there was a significant difference in powerlessness, meaninglessness and in the whole scale regarding seniority. The difference in powerlessness was detected among the teachers with 1-5 years of experience and 6-10 years of experience, among the teachers with 1-5 years of experience and 11-15 years of experience, among the teachers with 6-10 years of experience and 16 and over years of experience, among the teachers with 11-15 years of experience and 16 years and over years of experience. The difference in meaninglessness was detected among the teachers with 1-5 years of experience and 6-10 years of experience, among the teachers with 1-5 years of experience and 11-15 years of experience, among the teachers with 11-15 years of experience and 16 and over years of experience. The difference for the whole scale was detected among the teachers with 1-5 years of experience and 6-10 years of experience and among the teachers with $1-5$ years of experience and 11-15 years of experience.

\section{Conclusions and Recommendations}

In this part, the results of the research were examined and the studies in literature regarding to the research subjects were discussed in relation to the results in other studies. Then, some recommendations related to the results are presented for practitioners and researches.

\subsection{Conclusions}

The perceptions of public primary school teachers regarding organizational alienation behaviors were analyzed in terms of some variables (gender, marital status and seniority). The perceptions of the teachers participating in this study regarding organizational alienation behaviors were detected as $(\mathrm{M}=1,87)$ Rarely for the whole survey. Moreover, teachers were detected to be alienated in the level of Rarely on general in the studies carried out by Elma (2003)[18], Eryılmaz (2010) [28], Çağlayan (2015) [32], Şimşek, Balay and Şimşek (2012) [33]. Although the results were detected as Rarely, it is possible to adopt the behaviors that are not accepted by the society in order to achieve the goals of the success determined by social values. It should be tried to lower the level from Rarely to Never. Naturally, the behaviors of alienated employees affect the process of production and service and the quality of the product or service acquired badly. In the same way, teachers' behaviors of teaching and learning which are their fundamental duties are influenced badly by the feeling of alienation among teachers who are the employees in educational service that is one of the basic means of achieving social, economical, political, cultural, individual and technological development which is essential for the maintainance of the social being and modernization. This situation prevents the effectiveness of teaching and indirectly the realizationof students' behaviors which are requested to be obtained in teaching and learning process [34].

According to teachers' perceptions, the first three items with the highest average about alienation respectively; (1) I feel burnout and worn at work ( $M=2.53$, Rarely), (2) I think bureaucratic process at school impels me to obey unconditionally ( $M=2,51$, Rarely), (3) As soon as I finish my lessons, I want to leave the school $(\mathrm{M}=2,45$; Rarely). The results of this study were positive but not enough. It is proposed that the experience of certain dimensions of business and family life and the realities of the aging process are the major factors generating difficulties seen among professionals and managers. These difficulties involve attitudes of personel and social alienation that in turn may generate such changes in motivational processes as increased anxiety, lack of concern for self-actualization and decreased rationality. The result is a lack of interest in the real world, and therefore less rationality, one's unwillingness to express the real self (i.e.low level of self- actualization) [35]. Thus, school administrators should encourage teachers' participation regarding teachers'work and provide opportunities for implementing these decisions. School directors should help teachers realize their expectations and hopes, they should form democratic school performance, they should endeavor for strong communication, they should work in coordination with senior administrators so as to make the job of teaching attractive in terms of financial and spiritual ways, they should try to encourage teachers' motivation and they should reward successful teachers.

There was a significant difference in all dimensions except self-alienation and in the whole scale related to the teachers' perceptions regarding the level of alienation according to gender. Moreover, when the mean rank was analysed for the whole scale, the level of alienation of the male teachers was detected to be higher than their female collagues. The female teachers may be told to be more optimistic in their work life. According to the study by Çalışır (2006) [36], there was a significance in the teachers' perceptions regarding the gender variable and the male teachers were more alienated than the female ones. The study of Çevik (2009) [37] pointed out the fact that the male teachers were more alienated than the female teachers, the results of which are similar to the study of Çağlayan (2015) [32]. It is said that the male teachers cannot lead the events or they cannot deal with anything on their own compared to the female teachers. The male teachers worry about not being able to control future events due to their lack of the feeling of domination and they cannot evaluate themselves with real dimensions and their behaviors are controlled by other forces. Furthermore, they just know their job and they don't have any ideas about their colleagues and other parts of the school. They are not aware of their contribution to their schools. 
They adopt the behaviors that are not socially accepted in order to achieve the goals determined by social norms. They retreat from their their environment and they have the feeling of not belonging to any groups or communities. They refuse a group or community due to their point of views and they exclude the community that they are in. Moreover, the male teachers have difficulties making friends and communicating with people and they are estranged from the social environment.

There was no significant difference in all the dimensions and the whole scale related to the teachers' perceptions of organizational alienation regarding the level of alienation according to marital status. In other words, the perceptions of single and married teachers were similar. According to the study by Eryllmaz (2010) [28], there was no significant difference regarding the teachers' perceptions of organizational alienation according to marital status, the findings of which support these results.

A significant difference was detected in the dimensions of powerlessness, meaninglessness and the whole scale of the teachers' perceptions regarding organizational alienation behaviors related to their seniority. The difference among teachers' perceptions in the dimension of powerlessness was observed between 1-5 years and 6-10 years, between 1-5 years and 11-15 years, between 6-10 years and 16 years and over, between 11-15 years and 16 years and over. The difference in meaninglessness was observed among the teachers with 1-5 years of experience and 6-10 years of experience, among the teachers with 1-5 years and 11-15 years, among the teachers with $11-15$ years and 16 years and over. The difference for the whole scale was detected among the teachers with 1-5 years and 6-10 years, among the teachers with 1-5 years and 11-15 years. When the findings in table 4 were carefully analysed, the level of alienation in powerlessness and meaninglessness increased at the beginning of the work life from 1-5 years to the end of the fifteenth year. The level of alienation decreased after 16 years. Moreover, the highest level of alienation was observed among the teachers with 11-15 years of experience. The teachers in this group start to perceive their work, their work conditions and organizations in a more realistic way and they question their work life, which causes their hopelessness about their work life. The enthusiasm of the first day at work may turn into the disappointment and teachers may be in a dilemma over continuing the work, which may cause teachers to have negative attitudes and to be alienated. The teachers with 11-15 years experience who perform their work more practised compared to their first years and who still have a lot to learn may feel inadequate due to the fact that they cannot benefit from the new technology.

The effects of work alienation on employees are the lose of job and life satisfaction, low-productivity, low motivation, increasing work stress, low loyalty to work and organization, high labor turnover, absenteeism, estrangement from work and low perception of organizational well-being. The productivity of the employees spending most of their lives in organizations depend on personal and organizational well-being conditions. The inability of the employees to control work processes and products, the form of organizations based on automation, close supervision and authority issues, the inability of individuals to realize themselves cause organizational well-being problems [19].

\subsection{Recommendations for Practitioners and Researchers}

(1) According to the result of the study, teachers' alienation level for the whole scale was "Rarely". It should be tried to turn that level into "Never", so it should be insisted on the behaviors that prevent alienation by taking into consideration teachers' willingness and expectations, by strengthening communication within the organizations, by forming transparent form of administration and by being democratic administrators, by establishing open communication channels and by being administrators staying away from ignoring teachers' values. (2) It is a known fact that working place has crucial functions that control individual-organization crises. Thus, school administrators should establish a working atmosphere suitable for teachers' humanitarian needs. As a result, it can be told that a working environment with less alienation is formed. (3) Relevant experts should give different seminars to teachers and school administrators on the importance of organizational alienation. (4) Similar studies can be conducted in different levels of schools. (5) Observation and interview methods can be used. (6) The effect of teachers' organizational alienation behaviors on students' success can be researched. (7) Similar studies can be made in other cities and regions in Turkey comparatively. (8) Similar studies can be carried out by comparing state and private schools.

Note: This study was formed and partially developed from Emel Averbek's master thesis prepared in the consultation of Asst. Prof. Dr. Abidin Dağlı and was presented during Oral Abstract Sessions in International Contemporary Educational Research Congress (Education from tradition to future) held by Muğla Sitkı Koçman University Faculty of Education on 29th of September - 2nd of October 2016.

\section{REFERENCES}

[1] Akyıldız, H. (1998). Bireysel ve toplumsal boyutlarıyla yabancilaşma [Alienation with personel and social dimensions].The journal of faculty of economics and administrative sciences (3), 163-176.

[2] Shantz, A., Alfes, K., Bailey, C. \& Soane, E. (2015). Drivers and outcomes of work alienation. Journal of Management Inquiry, 24 (4), 382-393.

[3] Kongar, E. (1979). Toplumsal Değişim Kuramları ve Türkiye Gerçeği [Social change theories and the reality ofTurkey]. Ankara: Bilgi Yayınevi.

[4] Marshall, G. (1999). Sosyoloji sözlüğü [Dictionary of 
socialogy]. (Translated by: O. Akınhay \& D. Kömürcü). Ankara: Bilim ve Sanat Yayınları.

[5] Sookoo, N. (2014). Perceptions of Injusticeand Alienation Dynamics within the Workplace. Journal of the Department of Behavioural Sciences, 3 (1), 81-99.

[6] Banai, M. \& Reisel, W. D. (2007). The influence of supportive leadership and job characteristics on work alienation: A six-country investigation. Journal of World Business, 42 (4), 463-476.

[7] Nair, N. \& Vohra, N. (2010). An exploration of factors predicting work alienation of knowledge workers. Management Decision, 48 (4).600-615.

[8] Erjem, Y. (2005). Lise öğretmenleri üzerinde sosyolojik bir araştırma: Eğitimde yabancılaşma olgusu ve öğretmen: [The phenomenon of alienation in education a sosyological research on high school teachers]. Gazi University Journal of Turkish Educational Sciences. 4 (3), 1-22.

[9] Girijesh K. Y. \&Yashwant, K. N. (2012). Work alienation and occupational stress. Social Science International. 28 (2), 333-344.

[10] Ingleby, D. (1991). Erich Fromm the Sane Socety. London: Routledge Classics.

[11] Fromm, E. (2014). Sağllkl Toplum [Sane Society]. (Translated by: Y. Salman ve Z. Tanrisever). İstanbul: PayelYayınevi.

[12] Weisskopf, W.A. (1996). Alienation and Economy (Translated by: Koç, Ç., Madra, Y., Eryar, D., Erçel, K., Özselçuk, C., Önder,A.\& Badur. K.). İstanbul: Anahtar Kitaplar.

[13] Agarwal, S. (1993). Influence of formalization on role stress, organizational commitment, and work alienation of salespersons: A cross- national comparative study. Journal of International Business Studies, 24 (4), 715-739.

[14] Ceylan, A. \& Sulu, S. (2011). Organizational in justice and work alienation. Ekonomika a Management, (2),65-78.

[15] Hoy, W. K., Blazovsky, R. \&Newland, W. (1983). Bureaucracy and alienation: Acomparative analysis. The Journal of Educational Administration, 21 (2),109-121.

[16] Seeman, M. (1959).On the meaning of alienation. American Sociological Review. 24 (6), 783-791

[17] Eryılmaz, A. \& Burgaz, B. (2011). Lise öğretmenlerinin örgütsel yabancılaşma düzeyleri[Levels of organizational alienation for private and state high school teachers]. Ĕgitim ve Bilim [Education and Science].36 (161), 271-286.

[18] Elma, C. (2003). İlköğretim Okulu Öğretmenlerinin İșe Yabancllaşmasi[Teachers Work Alienation in Elementary School Ankara Case Study]. Unpublished doctoral thesis. Ankara university institute of social studies, Ankara.

[19] Tutar, H. (2014).Organizational Psychology. Ankara: Detay Yayıncilik

[20] Tan-Uçanok, B. (2016). The role of work centrality in the relationship between work alienation and organisational commitment. Journal for East European Management Studies. 21 (1), 60-81

[21] ] Efraty, D., Sirgy, J. M. \& Claiborne,C. B. ( 1991). The effects of personal alienation. Journalof Business and Psychology. 5 (1), 52-78

[22] Nettler, G. (1957). A measure of alienation. American Sociological Review. 22 (6), 670-677.

[23] Pugh, K.J. andZhao, Y. (2003). Stories of teacher alienation. Teaching and Teacher Education. 19 (2), 187-201

[24] Hoşgörür, V. (1997). Eğitim işgörenlerinin örgütsel tutumları. Samsun İli Örneği [Organizational behaviours of the teacher]. Doctoral dissertation. Ankara: Ankara university.

[25] Soza, J. (2015). Teacher alienation: Reconceptualizing the educational work environment the faculty of the school of education, A doctoral dissertation Loyola Marymount University, USA.

[26] Yıldız, K., Akgün, N. \&Yıldız, S. (2013). İșe yabancılaşma ile örgütsel sinizm arasındaki ilişki. [The relationship between work alienation and organizational cynicism] International Journal of Social Science, 6 (6), 1253-1284.

[27] Karasar, N. (2006). Bilimsel Araştırma Yöntemi[Scientific Research Method]. Ankara: Nobel Yayınları.

[28] Ery1lmaz, A. (2010). Lise öğretmenlerinin örgütsel yabancllaşma düzeyleri [Levels of organizational alienation for high school teachers]. Doctoral dissertation. Ankara: Hacettepe University.

[29] Tezbaşaran, A. (1997). Likert tipi ölçek hazırlama kılavuzu. [Likert type scale preparement guidebook]. Ankara: Association of Turkish Psychologists.

[30] Sipahi, B., Yurtkoru, S. \& Çinko, M. (2010). Sosyal bilimlerde SPSS'leveri analizi. [Data Analysis with SPSS in Social Studies]. İstanbul: Beta BasımYayım Dağıtım.

[31] Tavşancıl, E. \& Keser, H. (2001). İnternete yönelik likert tipi bir tutum ölçeğinin geliştirilmesi. [The development of likert type-attitude scale questionnaire]. Ankara University Journal of Educational Sciences, 34 (2), 45-60.

[32] Çağlayan, A. (2015). Imam Hatip Ortaokullarında Görevli Öğretmenlerin İşe Yabancılaşmasina Ilişkin Algllarl[Perceptions of imam hatip secondary school teachers regarding work alienation]. Unpublished master thesis. Zirve university institute of social sciences, Gaziantep.

[33] Şimșek, H., Balay, R. ve Şimșek, A. S. (2012). İlköğretim sınıf öğretmenlerinde mesleki yabancılaşma [Vocational alienation of primary school teachers]. Eğitim Bilimleri Araştırma Dergisi, [Journal of Educational Sciences Research], 2 (1),54-72.

[34] Mercan, S. (2010). Performansa Dayalı Ücret Sisteminin Örgütsel Vatandaşlık Davranışı̈̈zerine Etkileri ve Bir Uygulama [The relationship between the pay-based performance system and the organizational citizenship behavior and a research]. Unpublished master thesis. İstanbuluniversity institute of social sciences, Istanbul.

[35] Korman, A. K., Wittig-Berman, U. \& Lang, D. (1981). Career success and personal failure: Alienation in professionals and managers. Academy of Management Journal. 24 (2), 342-360.

[36] Çalışır, İ. (2006). Illköğretim okulu öğretmenlerinin işe yabancılaşması Bolu ili örneği [Teachers work alienation in elementary school]. Unpublished master thesis. Abant İzzet Baysal University institue of social sciences, Bolu. 
[37] Çevik, R. (2009). Ortaöğretim Kurumlarında Yönetici Davranışlarının Öğretmenlerin Mesleklerine

Yabancilaşmasina Etkisi [The influence of behaviors of administrators on the alienation of teachers to their jobs]. Unpublished master thesis. Yeditepe University institue of social sciences, İstanbul. 